\section{Eastern Filbert Blight-resistant Hazelnuts from Russia, Ukraine, and Poland}

\author{
John M. Capik and Megan Muehlbauer \\ Department of Plant Biology and Pathology, Foran Hall, 59 Dudley Road, \\ Rutgers University, New Brunswick, NJ 08901
}

Ari Novy

United States Botanic Garden, 245 First Street, SW, Washington, DC 20024

Josh A. Honig and Thomas J. Molnar ${ }^{1}$

Department of Plant Biology and Pathology, Foran Hall, 59 Dudley Road, Rutgers University, New Brunswick, NJ 08901

Additional index words. Anisogramma anomala, Corylus avellana, disease resistance, nut crops, tree breeding

\begin{abstract}
Stable genetic resistance to the fungal disease eastern filbert blight (EFB), caused by Anisogramma anomala, is vital for sustainable production of European hazelnut (Corylus avellana) in eastern North America. In this study, new hazelnut germplasm from the Russian Federation, Ukraine, and Poland (a total of 1844 trees from 66 seed lots) was subjected to $A$. anomala under field conditions over at least five years in New Jersey. Plants were then rated for the presence of EFB using an index of 0 (no disease) through 5 (all stems containing cankers). Nuts of the resistant trees were evaluated to identify plants with improved kernel characteristics. Genomic DNA of these trees was also screened with sequence-characterized amplified region (SCAR) markers generated by the primers BE-03, BE-33, and BE-68, which are closely linked to the single dominant $\boldsymbol{R}$-gene of 'Gasaway', to assess the resistant seedlings for the presence of this well-known source of resistance. At final evaluation, 76 trees remained free of disease with nine expressing only minor symptoms (rating 1 or 2). The resistant trees spanned 24 different seed lots representing all three countries. The remaining trees ranged from moderately to severely infected with $81 \%$ of the total collection rating 5 . Several of the resistant trees were found to produce commercial-sized $(\approx 12 \mathrm{~mm}$ diameter $)$, round kernels that blanched well. Although the results of the 'Gasaway' SCAR primers were inconclusive, the diverse collection origins and disease phenotypes provide evidence that novel sources of resistance were likely identified in this study. These new plants should broaden the genetic base of EFB-resistant $C$. avellana hazelnut germplasm available for breeding.
\end{abstract}

Eastern filbert blight, caused by the ascomycete fungus Anisogramma anomala, is an endemic disease of the wild American hazelnut, Corylus americana. This pathogen is associated with $C$. americana throughout its native range, which spans much of the United States and southern Canada, east of the Rocky Mountains (Gleason and Cronquist, 1998). Although EFB is typically inconsequential

\footnotetext{
Received for publication 29 Jan. 2013. Accepted for publication 5 Mar. 2013.

Funding comes from the New Jersey Agricultural Experiment Station, the Rutgers Center for Turfgrass Science, the Northern Nut Growers Association, Hatch funds provided by USDA-NIFA, and the USDA-NIFA Specialty Crops Research Initiative Competitive Grant 2009-51181-06028.

We thank C.R. Funk, D. Zaurov, A. Morgan, E. Durner, and S. Mehlenbacher as well as the Russian Academy of Agricultural Science Institute of Floriculture and Subtropical Cultures, Sochi, Russia, for their contributions to this study.

${ }^{1}$ To whom reprint requests should be addressed; e-mail molnar@aesop.rutgers.edu.
}

to C. americana (Capik and Molnar, 2012; Fuller, 1908; Weschcke, 1954), it causes severe cankering, branch dieback, and eventual death of most cultivars of the commercially important European hazelnut, C. avellana (Johnson and Pinkerton, 2002). This disease is considered to be the principle limiting factor of hazelnut production in the eastern United States (Thompson et al., 1996).

Today, $99 \%$ of U.S. hazelnut production occurs in the Willamette Valley of Oregon, representing $\approx 5 \%$ of the world crop, which was 857,759 t in 2010 (Food and Agricultural Organization of the United Nations, 2012). When the hazelnut industry began in the Pacific northwestern United States in the early 1900s, EFB was not present (Barss, 1930). The suitable climate of the region, combined with the lack of EFB, allowed for production to flourish for almost a century. This scenario changed dramatically with the introduction of $A$. anomala into southwest Washington in the 1960s (Davison and Davidson, 1973). In the early years after its introduction, EFB devastated orchards because effective control measures were not yet developed (Gottwald and Cameron, 1980; Pinkerton et al., 1992). It was later learned that scouting for cankers, therapeutic pruning, and copious fungicide applications were necessary to continue production in the presence of the disease (Johnson et al., 1996). As a result of the expense of these control measures and the fact that hazelnut was traditionally a low-input crop, the development and production of EFB-resistant cultivars has been recognized as a more cost-effective, long-term management solution (Julian et al., 2008, 2009; Thompson et al., 1996). Breeding for EFB resistance is now a major objective of hazelnut breeding programs in the United States (Mehlenbacher, 1994; Molnar et al., 2005a).

Recent taxonomic studies suggest Corylus contains 11 species (Bassil et al., 2013; Erdogan and Mehlenbacher, 2000). Of these species, cultivated forms of $C$. avellana produce the largest nuts with the most desirable kernel characteristics with the remaining species generally producing tiny, thick-shelled nuts (Mehlenbacher, 1991). Therefore, the identification of EFB resistance within $C$. avellana holds promise for more efficient breeding of commercial-quality, EFB-resistant cultivars. This assumption is the result of the likely need for fewer backcross generations if genes for EFB resistance are identified in plants that also produce nuts of improved quality. The first identified C. avellana cultivar resistant to EFB was Gasaway, a lateblooming pollenizer that produces low yields of small, poor-quality nuts. Despite its horticultural deficiencies, 'Gasaway' was shown to transmit a dominant allele at a single locus that confers resistance to its offspring in a ratio of one resistant to one susceptible (Mehlenbacher et al., 1991). Since its discovery, it has been widely used in the Oregon State University (OSU), Corvallis, OR, hazelnut breeding program. After nearly 30 years of breeding, EFB-resistant cultivars that produce commercial-quality nuts were recently released from OSU, including 'Santiam' (Mehlenbacher et al., 2007), 'Yamhill' (Mehlenbacher et al., 2009), and 'Jefferson' (Mehlenbacher et al., 2011).

Concern over the long-term durability of using only one source of resistance to the EFB pathogen led to the initiation of research at OSU to find additional resistant plants. This work eventually yielded a number of $C$. avellana cultivars and seedling selections as well as other Corylus species and interspecific hybrids found to be resistant to EFB in Oregon (Chen et al., 2005, 2007; Coyne et al., 1998; Lunde et al., 2000; Sathuvalli et al., 2009, 2010). Along with 'Gasaway', a number of these new sources of resistance is being incorporated into advanced breeding selections at OSU, which is being facilitated by the use of marker-assisted selection (MAS) (S.A. Mehlenbacher, personal communication). Mehlenbacher et al. (2004) identified a number of random amplified polymorphic DNA (RAPD) markers tightly linked to the 'Gasaway' $R$-gene with the primers UBC $152_{800}$, UBC $268_{580}$, and OP AA $12_{850}$ used routinely 
in the OSU breeding program. Recently, SCAR markers developed from the RAPD markers linked to the Gasaway $R$-gene have also been developed for use in fine mapping around the 'Gasaway' resistance locus and have shown application for MAS (Sathuvalli and Mehlenbacher, 2010). In addition to 'Gasaway', other polymerase chain reactionbased molecular markers have been developed that are closely linked to the $R$-genes found in $C$. avellana 'Ratoli' (from Spain), OSU 408.040 (from Minnesota), and OSU 750.010 (from the Republic of Georgia) (Chen et al., 2005; Mehlenbacher et al., 2004; Sathuvalli et al., 2011a, 2011b, 2012). Using these primers, one can identify seedlings that carry the specific resistance allele within weeks of germination in the absence of the EFB pathogen. This technique provides a very significant time reduction over greenhouse inoculation methods, in which trees are required to cycle through a period of plant dormancy before EFB cankers can be visualized and can take between nine and 24 months (Johnson et al., 1994; Molnar et al., 2005b). In addition to offering a more efficient disease selection method, MAS can also facilitate the "pyramiding" of two or more resistance genes into one cultivar as a possible means to develop plants expressing more durable forms of disease resistance.

Recent work at Rutgers University, New Brunswick, NJ, has shown that pathogenic variation may exist in $A$. anomala. A number of hazelnut genotypes, including 'Gasaway' and some of its offspring known to be resistant to the isolates of the fungus present in Oregon, were recently found to be susceptible when exposed to eastern U.S. isolates in greenhouse inoculations and through longterm field trials. Conversely, a number of other genotypes ('Ratoli', 'Zimmerman', OSU 495.072, 'Grand Traverse', and OSU 541.147) were exposed similarly and remained free of disease (Capik and Molnar, 2012; Molnar et al., 2010a, 2010b). These findings support the need to continue efforts toward the identification and study of new sources of genetic resistance to $A$. anomala, especially the assessment of new germplasm in areas where the pathogen is native and disease pressure is high.

The objective of this study was to evaluate new introductions of hazelnut germplasm from Russia, the Ukraine, and Poland for their response to $A$. anomala under field conditions in New Jersey to identify new sources of resistance and tolerance to EFB. Nut and kernel attributes of the resistant and tolerant trees would then be characterized to identify improved, EFB-resistant seedlings expressing the greatest potential value for genetic improvement efforts.

\section{Materials and Methods}

Plant material and culture. Hazelnut germplasm in the form of nuts resulting from open pollination was collected from southern Russia in 2002 and 2004, the Crimean Peninsula of the Ukraine in 2002, and Konskowli, Skierniewice, and Warsaw, Poland, in 2006. A total of 66 seed lots was obtained from horticultural institutes and breeding stations as well as purchased from local roadside vendors and outdoor markets in late August or early September of each collection year. Their origin and specific seed parent, when known, are listed in Table 1. Nuts collected from the institutes were largely harvested directly from the trees before nut fall, which helped to avoid the mixing of nuts from different parent plants. No background information (cultivar, previous storage conditions, etc.) was available from the seed lots

Table 1. Summary of response of Corylus avellana germplasm from Russia, Ukraine, and Poland to eastern filbert blight (EFB; Anisogramma anomala).

\begin{tabular}{|c|c|c|c|c|c|c|c|c|c|c|}
\hline \multirow[b]{2}{*}{ Seed lot } & \multirow[b]{2}{*}{ Yr planted } & \multirow[b]{2}{*}{ Origin and parentage } & \multirow[b]{2}{*}{ Trees(no.) } & \multicolumn{7}{|c|}{ Eastern filbert blight ratings $^{\mathrm{y}}$} \\
\hline & & & & Mean $^{z}$ & 0 & 1 & 2 & 3 & 4 & 5 \\
\hline$\overline{04018 \mathrm{R}^{\mathrm{x}}}$ & 2005 & 'Chikvistava' $\times$ open-pollinated (OP), Sochi, Russia & 59 & $4.98_{\mathrm{a}}$ & 0 & 0 & 0 & 0 & 1 & 58 \\
\hline $04019 \mathrm{R}$ & 2005 & 'Ata Baba' $\times$ OP, Sochi, Russia & 8 & $4.88_{\mathrm{a}}$ & 0 & 0 & 0 & 0 & 1 & 7 \\
\hline $04021 \mathrm{R}$ & 2005 & 'Cherkeskii II' $\times$ OP, Sochi, Russia & 38 & $4.89_{\mathrm{a}}$ & 0 & 0 & 0 & 0 & 4 & 34 \\
\hline $04022 \mathrm{R}$ & 2005 & 'President' $\times$ OP, Sochi, Russia & 17 & $4.00_{\mathrm{abc}}$ & 2 & 0 & 0 & 3 & 1 & 11 \\
\hline $04023 \mathrm{R}$ & 2005 & 'Christina' $\times$ OP, Sochi, Russia & 7 & $4.86_{\mathrm{a}}$ & 0 & 0 & 0 & 0 & 1 & 6 \\
\hline $04024 \mathrm{R}$ & 2005 & 'Zugdui' $\times$ OP, Sochi, Russia & 45 & $4.07_{\mathrm{abc}}$ & 1 & 1 & 0 & 11 & 11 & 21 \\
\hline $04025 \mathrm{R}$ & 2005 & B-X-2 × OP, Sochi, Russia & 36 & $4.97_{\mathrm{a}}$ & 0 & 0 & 0 & 0 & 1 & 35 \\
\hline $04026 \mathrm{R}$ & 2005 & Unknown seed mixture, Sochi region, Russia & 24 & $4.75_{\mathrm{a}}^{a}$ & 1 & 0 & 0 & 0 & 1 & 22 \\
\hline $04027 \mathrm{R}$ & 2005 & 'Akademik Yabokov' $\times$ OP, Sochi, Russia & 31 & $5.00_{\mathrm{a}}$ & 0 & 0 & 0 & 0 & 0 & 31 \\
\hline $04028 \mathrm{R}$ & 2005 & 'Kavkas' × OP, Sochi, Russia & 37 & $4.70_{\mathrm{ab}}$ & 2 & 0 & 0 & 0 & 1 & 34 \\
\hline $04029 \mathrm{R}$ & 2005 & 'Abhazki' $\times$ OP, Sochi, Russia & 27 & $4.63_{\mathrm{ab}}$ & 1 & 0 & 0 & 0 & 5 & 21 \\
\hline $04030 \mathrm{R}$ & 2005 & 'Moskovskii Rubin' × OP, Sochi, Russia & 54 & $3.31_{\mathrm{bc}}$ & 18 & 0 & 0 & 0 & 1 & 35 \\
\hline $04031 \mathrm{R}$ & 2005 & 'Victoria' $\times$ OP, Sochi, Russia & 52 & $4.96 \mathrm{a}$ & 0 & 0 & 0 & 0 & 2 & 50 \\
\hline $04032 \mathrm{R}$ & 2005 & Unknown seed mixture, Sochi region, Russia & 59 & $4.81_{\mathrm{a}}$ & 0 & 0 & 0 & 1 & 9 & 49 \\
\hline $04033 \mathrm{R}$ & 2005 & 'Anastasia' $\times$ OP, Sochi, Russia & 22 & $4.77_{\mathrm{a}}$ & 0 & 1 & 0 & 0 & 1 & 20 \\
\hline $04034 \mathrm{R}$ & 2005 & Unknown seedling, Sochi region, Russia & 39 & $4.64_{\mathrm{ab}}$ & 1 & 0 & 0 & 0 & 9 & 29 \\
\hline $04035 \mathrm{R}$ & 2005 & Wild $C$. avellana, Sochi region, Russia & 25 & $4.88_{\mathrm{a}}$ & 0 & 0 & 0 & 0 & 3 & 22 \\
\hline $04036 \mathrm{R}$ & 2005 & Unknown seedling, Sochi region, Russia & 3 & $5.00 \mathrm{a}$ & 0 & 0 & 0 & 0 & 0 & 3 \\
\hline $04037 \mathrm{R}$ & 2005 & 'Trapezund' $\times$ OP, Sochi, Russia & 2 & $5.00_{\mathrm{a}}$ & 0 & 0 & 0 & 0 & 0 & 2 \\
\hline $04038 \mathrm{R}$ & 2005 & B-X-1 $\times$ OP, Sochi, Russia & 58 & $4.86_{\mathrm{a}}$ & 1 & 0 & 0 & 0 & 3 & 54 \\
\hline $04039 \mathrm{R}$ & 2005 & Unknown seedling, Sochi region, Russia & 12 & $4.58_{\mathrm{ab}}$ & 0 & 0 & 0 & 0 & 5 & 7 \\
\hline $04040 \mathrm{R}$ & 2005 & 'Rimskii' $\times$ OP, Sochi, Russia & 49 & $4.86_{\mathrm{a}}$ & 1 & 0 & 0 & 0 & 2 & 46 \\
\hline $04041 \mathrm{R}$ & 2005 & B-X-3 $\times$ OP, Sochi, Russia & 45 & $4.73_{\mathrm{a}}$ & 1 & 0 & 0 & 1 & 5 & 38 \\
\hline $06050 \mathrm{P}$ & 2007 & 'Garibaldi' × OP, Konskowli, Poland & 15 & $4.87 \mathrm{a}$ & 0 & 0 & 0 & 1 & 0 & 14 \\
\hline $06051 \mathrm{P}$ & 2007 & 'Webba' $\times$ OP, Konskowli, Poland & 29 & $4.86_{\mathrm{a}}$ & 0 & 0 & 0 & 0 & 4 & 25 \\
\hline $06052 \mathrm{P}$ & 2007 & 'Halls Giant' $\times$ OP, Konskowli, Poland & 8 & $5.00_{\mathrm{a}}$ & 0 & 0 & 0 & 0 & 0 & 8 \\
\hline $06053 \mathrm{P}$ & 2007 & 'Katalonski' × OP, Konskowli, Poland & 27 & $4.81_{\mathrm{a}}$ & 0 & 0 & 0 & 1 & 3 & 23 \\
\hline $06054 \mathrm{P}$ & 2007 & Unknown seed mixture, Skierniewice, Poland & 157 & $4.64_{\mathrm{ab}}$ & 2 & 0 & 2 & 9 & 28 & 116 \\
\hline $06077 \mathrm{P}$ & 2007 & Warsaw Market \#1, Warsaw, Poland & 18 & $5.00_{\mathrm{a}}$ & 0 & 0 & 0 & 0 & 0 & 18 \\
\hline $06078 \mathrm{P}$ & 2007 & Warsaw Market \#2, Warsaw, Poland & 14 & $5.00_{\mathrm{a}}$ & 0 & 0 & 0 & 0 & 0 & 14 \\
\hline $06079 \mathrm{P}$ & 2007 & Warsaw Market \#3, Warsaw, Poland & 21 & $4.86_{\mathrm{a}}$ & 0 & 0 & 0 & 1 & 1 & 19 \\
\hline $06080 \mathrm{P}$ & 2007 & Warsaw Market \#4, Warsaw, Poland & 20 & $4.70_{\mathrm{ab}}$ & 1 & 0 & 0 & 0 & 1 & 18 \\
\hline $06081 \mathrm{P}$ & 2007 & Warsaw Market \#5, Warsaw, Poland & 9 & $4.89 \mathrm{a}$ & 0 & 0 & 0 & 0 & 1 & 8 \\
\hline $06082 \mathrm{P}$ & 2007 & Warsaw Market \#6, Warsaw, Poland & 12 & $4.92_{\mathrm{a}}$ & 0 & 0 & 0 & 0 & 1 & 11 \\
\hline $06083 \mathrm{P}$ & 2007 & Warsaw Market \#7, Warsaw, Poland & 12 & $5.00_{\mathrm{a}}^{\mathrm{a}}$ & 0 & 0 & 0 & 0 & 0 & 12 \\
\hline $06084 \mathrm{P}$ & 2007 & Warsaw Market \#8, Warsaw, Poland & 16 & $4.81_{\mathrm{a}}$ & 0 & 0 & 0 & 1 & 1 & 14 \\
\hline $06085 \mathrm{P}$ & 2007 & Unknown seed mixture, Warsaw, Poland & 57 & $4.63_{\mathrm{ab}}$ & 4 & 0 & 0 & 0 & 1 & 52 \\
\hline RUS-1 & 2003 & $\begin{array}{l}\text { Unknown seed mixture, Institute of Floriculture and } \\
\text { Subtropical Cultures, Sochi, Russia }\end{array}$ & 71 & $4.77_{\mathrm{a}}$ & 0 & 0 & 0 & 2 & 12 & 57 \\
\hline
\end{tabular}


Table 1. (Continued) Summary of response of Corylus avellana germplasm from Russia, Ukraine, and Poland to eastern filbert blight (EFB; Anisogramma anomala).

\begin{tabular}{|c|c|c|c|c|c|c|c|c|c|c|}
\hline \multirow[b]{2}{*}{ Seed lot } & \multirow[b]{2}{*}{ Yr planted } & \multirow[b]{2}{*}{ Origin and parentage } & \multirow[b]{2}{*}{ Trees(no.) } & \multicolumn{7}{|c|}{ Eastern filbert blight ratings ${ }^{\mathrm{y}}$} \\
\hline & & & & Mean $^{z}$ & 0 & 1 & 2 & 3 & 4 & 5 \\
\hline$\overline{\text { RUS-2 }}$ & 2003 & $\begin{array}{l}\text { ‘Kudashovski’ } \times \text { OP, Institute of Floriculture and } \\
\text { Subtropical Cultures, Sochi, Russia }\end{array}$ & 61 & $3.08_{\mathrm{c}}$ & 23 & 0 & 0 & 0 & 2 & 36 \\
\hline RUS-3 & 2003 & Sochi Market \#1, Sochi, Russia & 13 & $4.15_{\mathrm{abc}}$ & 0 & 0 & 1 & 2 & 4 & 6 \\
\hline RUS-4 & 2003 & Sochi Market \#2,Sochi, Russia & 19 & $3.16_{\mathrm{c}}$ & 4 & 2 & 0 & 3 & 1 & 9 \\
\hline RUS-5 & 2003 & Sochi Market \#3, Sochi, Russia & 26 & $4.92_{\mathrm{a}}$ & 0 & 0 & 0 & 0 & 2 & 24 \\
\hline RUS-6 & 2003 & Sochi Market \#4, Sochi, Russia & 25 & $4.84 \mathrm{a}$ & 0 & 0 & 0 & 1 & 2 & 22 \\
\hline RUS-7 & 2003 & Sochi Market \#5, Sochi, Russia & 15 & $3.93_{\mathrm{abc}}$ & 1 & 0 & 1 & 2 & 4 & 7 \\
\hline RUS-8 & 2003 & Sochi Market \#6, Sochi Russia & 10 & $5.00_{\mathrm{a}}$ & 0 & 0 & 0 & 0 & 0 & 10 \\
\hline RUS-9 & 2003 & Holmskij Market \#1; Holmskij, Krasnodarskiy Kray, Russia & 10 & $5.00_{\mathrm{a}}$ & 0 & 0 & 0 & 0 & 0 & 10 \\
\hline RUS-10 & 2003 & Holmskij Market \#2; Holmskij, Krasnodarskiy Kray, Russia & 14 & $4.93 \mathrm{a}$ & 0 & 0 & 0 & 0 & 1 & 13 \\
\hline RUS-11 & 2003 & Holmskij Market \#3; Holmskij, Krasnodarskiy Kray, Russia & 24 & $4.04 \mathrm{abc}$ & 4 & 0 & 0 & 1 & 1 & 18 \\
\hline RUS-12 & 2003 & Holmskij Market \#4; Holmskij, Krasnodarskiy Kray, Russia & 7 & $4.57_{\mathrm{ab}}$ & 0 & 0 & 0 & 1 & 1 & 5 \\
\hline RUS-13 & 2003 & Holmskij Market \#5; Holmskij, Krasnodarskiy Kray, Russia & 9 & $4.78_{\mathrm{a}}$ & 0 & 0 & 0 & 0 & 2 & 7 \\
\hline RUS-14 & 2003 & Holmskij Market \#6; Holmskij, Krasnodarskiy Kray, Russia & 33 & $4.36_{\mathrm{abc}}$ & 0 & 0 & 0 & 4 & 13 & 16 \\
\hline RUS-15 & 2003 & $\begin{array}{l}\text { Mixed cultivars, Vavilov Research Institute of Plant Industry (VIR) } \\
\text { Breeding Station; Maykop, Russia }\end{array}$ & 66 & $4.76_{\mathrm{a}}$ & 1 & 0 & 0 & 1 & 9 & 55 \\
\hline RUS-16 & 2003 & $\begin{array}{l}\text { 'Badem' } \times \text { OP, Research Institute for Horticulture } \\
\text { and Viticulture; Krasnodar, Russia }\end{array}$ & 19 & $4.26_{\mathrm{abc}}$ & 0 & 0 & 0 & 1 & 12 & 6 \\
\hline RUS-17 & 2003 & Krasnodar Market \#1; Krasnodar, Russia & 9 & $4.78 \mathrm{a}$ & 0 & 0 & 0 & 1 & 0 & 8 \\
\hline RUS-18 & 2003 & Krasnodar Market \#2; Krasnodar, Russia & 18 & $4.72 \mathrm{a}$ & 0 & 0 & 0 & 0 & 5 & 13 \\
\hline RUS-19 & 2003 & Krasnodar Market \#3; Krasnodar, Russia & 35 & $4.86_{\mathrm{a}}$ & 0 & 0 & 0 & 0 & 5 & 30 \\
\hline RUS-20 & 2003 & Krasnodar Market \#4; Krasnodar, Russia & 17 & $4.88_{\mathrm{a}}$ & 0 & 0 & 0 & 0 & 2 & 15 \\
\hline RUS-21 & 2003 & Simferopol Roadside Market \#1A; near Simferopol, Crimea, Ukraine & 16 & $4.38_{\mathrm{abc}}$ & 1 & 1 & 0 & 0 & 1 & 13 \\
\hline RUS-22 & 2003 & Simferopol Roadside Market \#1B; near Simferopol, Crimea, Ukraine & 20 & $4.85_{\mathrm{a}}$ & 0 & 0 & 0 & 0 & 3 & 17 \\
\hline RUS-23 & 2003 & Simferopol Roadside Market \#2; near Simferopol, Crimea, Ukraine & 18 & $4.56_{\mathrm{ab}}$ & 1 & 0 & 0 & 0 & 3 & 14 \\
\hline RUS-24 & 2003 & Simferopol Roadside Market \#3; near Simferopol, Crimea, Ukraine & 16 & $4.16_{\mathrm{ab}}$ & 0 & 0 & 0 & 0 & 5 & 11 \\
\hline RUS-25 & 2003 & Simferopol Roadside Market \#4; near Simferopol, Crimea, Ukraine & 22 & $4.27 \mathrm{abc}$ & 1 & 0 & 0 & 1 & 9 & 11 \\
\hline RUS-26 & 2003 & Simferopol Roadside Market \#5; near Simferopol, Crimea, Ukraine & 13 & $3.08_{\mathrm{c}}$ & 4 & 0 & 0 & 1 & 3 & 5 \\
\hline RUS-28 & 2003 & Nikita Botanical Garden \#1; Yalta, Crimea, Ukraine & 35 & $4.89 \mathrm{a}$ & 0 & 0 & 0 & 1 & 2 & 32 \\
\hline RUS-29 & 2003 & Nikita Botanical Garden \#2; Yalta, Crimea, Ukraine & 34 & $4.97 \mathrm{a}$ & 0 & 0 & 0 & 0 & 1 & 33 \\
\hline RUS-31 & 2003 & Wild C. avellana, near Moscow, Russia & 5 & $5.00_{\mathrm{a}}$ & 0 & 0 & 0 & 0 & 0 & 5 \\
\hline & & Totals & 1844 & 4.6 & 76 & 5 & 4 & 51 & 213 & 1495 \\
\hline
\end{tabular}

zProgeny means followed by a different letter in the column are considered significantly different $(P<0.05)$ based on a Ryan-Einot-Gabriel-Welsch (REGWQ) test using the REGWQ option of PROC GLM in SAS [Version 9.2; SAS Institute, Cary, NC (SAS Institute, Inc., 2012)].

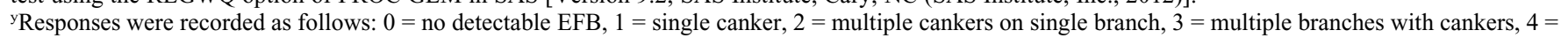

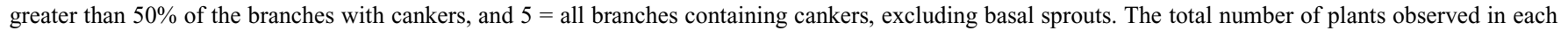
disease category ( 0 through 5$)$ for each progeny is listed in each column below the disease rating category.

${ }^{x}$ All seeds collected in 2004 (04018 R through 04041 R) and planted in 2005 were collected from the Institute of Floriculture and Subtropical Cultures, Sochi, Russian Federation, unless otherwise noted.

purchased as fresh in-shell nuts from local markets and some obviously constituted mixtures of nuts from different genetic backgrounds. Nuts were held in mesh bags at ambient room temperatures $\left(\approx 20^{\circ} \mathrm{C}\right)$ for 2 to 3 weeks to dry and were then placed in cold storage until undergoing moist-chilling at $4{ }^{\circ} \mathrm{C}$ from October to March. They were germinated in wooden planting boxes $(61 \mathrm{~cm} \times$ $91 \mathrm{~cm} \times 15 \mathrm{~cm})$ containing a peat-based medium (Promix ${ }^{\circledR}$ BX; Premier Horticulture, Rivière-du-Loup, Québec, Canada) in a greenhouse maintained at $24 / 18{ }^{\circ} \mathrm{C}$ (day/ night) with 16-h daylengths. In 4 to 6 weeks, seedlings were transplanted to $3.7-\mathrm{L}$ plastic containers using the same planting medium. Each plant was top-dressed with $5 \mathrm{~g}$ of five- to six-month time-release fertilizer (Osmocote Plus $15 \mathrm{~N}-9 \mathrm{P}_{2} \mathrm{O}_{5}-12 \mathrm{~K}_{2} \mathrm{O}$ with micronutrients; The Scotts Co., Marysville, $\mathrm{OH}$ ) and watered as needed. It must be noted that each seed source from the 2002 collection [RUS- 1 to RUS-31, except RUS-2 (Table 1)] was divided after germination and transplanting. Half of the resulting plants was exposed to severe greenhouse inoculations with the EFB pathogen and were discussed in Molnar et al. (2007). The remaining plants forwent greenhouse inoculations to be evaluated under longer-term field exposure to $A$. anomala in this study, which provides a more effective means to identify levels of tolerance to EFB (Coyne et al., 2000). None of the seedlings from the 2004 and 2006 collection (seed lots $04018 \mathrm{R}$ to $04041 \mathrm{R}$ and $06050 \mathrm{P}$ to $06085 \mathrm{P}$, respectively) were exposed to greenhouse inoculations. After transplanting, seedlings were maintained in the greenhouse until early June or July and were then moved outside under $40 \%$ shadecloth until field-planting in September or October. Trees were planted in blocks by progeny, with the progenies organized in a completely randomized design at a spacing of 0.45 or $0.91 \mathrm{~m}$ within rows by $3.66 \mathrm{~m}$ between rows at either the Rutgers Fruit Research and Extension Center, Cream Ridge, NJ, or the Rutgers Vegetable Research and Extension Farm, North Brunswick, NJ. Weed control, irrigation, and fertilizer were provided as needed over the course of the study with no applications of fungicides or insecticides.

Exposure to eastern filbert blight. Plants were exposed to EFB through natural spread from adjacent breeding nurseries holding many hundreds of infected hazelnut plants in addition to field inoculations, which consisted of tying infected hazelnut stems into the canopies of each tree in early April annually. The infected stems were collected from the Rutgers Fruit Research and Extension Center and the Rutgers Vegetable Research and Extension Farm. Disease pressure increased as the study progressed and EFB spread among the susceptible plants, which later constituted a large majority of the overall plantings.

Evaluation of disease response. In Jan. 2012, a thorough visual rating of disease incidence and severity was recorded for all trees in the study according to an index developed by Pinkerton et al. (1992): $0=$ no detectable EFB; $1=$ single canker; $2=$ multiple cankers on a single branch; $3=$ multiple branches with cankers; $4=$ greater than $50 \%$ of branches have cankers; $5=$ all branches containing cankers, except for basal sprouts. The ratings of the individual trees were then used to calculate a mean disease rating for each seed lot with means separated with the Ryan-EinotGabriel-Welsch (REGWQ) test using the REGWQ option of PROC GLM in SAS [Version 9.2; SAS Institute, Cary, NC (SAS Institute, Inc., 2012)]. As a general point of reference, trees rating 0 are considered resistant. Trees rating 1 or 2 are considered highly tolerant, because, in our experience, 
they typically do not develop large enough cankers over the long term to impede normal growth or nut production. Trees rating 3 are regarded as moderately tolerant, where it is unlikely that tree death will occur, although branches continue to die leading to a reduction in nut yield over time. Trees rating 4 or 5 are regarded as susceptible, where they show significantly reduced growth within two years of exposure and typically die entirely within five to seven years.

Nut and kernel evaluations. Nuts were harvested directly from the plants before nut fall to prevent loss of product as a result of predation from rodents. The harvest was carried out in late Aug. through early Sept. 2012 from nearly all plants rating 0 or 1 . Thirteen EFB-resistant plants selected from related seed lots from Russia and the Ukraine, identified in Molnar et al. (2007), were also included for comparison and documentation, because their nuts were not evaluated in the previous publication. Collected nuts were husked and dried indoors in mesh bags $\left(\approx 20^{\circ} \mathrm{C}\right)$. They were placed on ventilated storage shelves with circulating fans run continuously for $\approx 8$ weeks before evaluation. Total intact nut weight and kernel weight of 10 typical, individual nuts were recorded for each tree and used to calculate kernel percentage [(kernel weight/total nut weight $\times 100$ ]. Then, where available, 50 nuts were cracked and the number of good (free of defects) and substandard (blank, moldy, poorly filled, shriveled, or twinned) kernels were recorded and used to calculate the overall percentages of each of these defects. Presence of fiber on the kernels was rated using a scale of $1=$ no fiber present to $4=$ very fibrous (Thompson et al., 1978). The length, width, and thickness (depth) of 10 typical kernels of each seedling were measured with a digital caliper to calculate average kernel dimensions. These dimensions were used to calculate the geometric mean diameter $(D g)$ and sphericity (index of roundness) $(\Phi)$ of the kernels using the formula $D g=(\mathrm{LWT})^{1 / 3}$ and $\Phi=[D g / \mathrm{L}] \times$ 100 , where $\mathrm{L}=$ length, $\mathrm{W}=$ width, and $\mathrm{T}=$ thickness in millimeters (Mohsenin, 1970).

Furthermore, using $\approx 20$ kernels, the ease of pellicle removal after dry heat $\left(130^{\circ} \mathrm{C}\right.$ for $13.5 \mathrm{~min}$, then rubbing the cooled kernels with a terry cloth towel) was rated on a scale of $1=$ complete pellicle removal to $7=$ no pellicle removal (Mehlenbacher and Smith, 1988; Thompson et al., 1978). Nut and kernel attributes were subjected to statistical analysis using analysis of variance (ANOVA), including Fisher's least significant-difference test (PROC ANOVA) in SAS for all measurements with sufficient data points (Tables 2 and 3$)$.

SCAR primer assessment. In May 2012, leaf samples were collected from 70 of the total 81 plants rating 0 or 1 as well as all 13 plants identified in Molnar et al. (2007) to undergo genomic DNA extraction and screening for the presence of SCAR markers BE-03, BE-33, and BE-68. These markers are closely linked (less than $1 \mathrm{cM}$ ) to the

Table 2. Analysis of variance results of nut and kernel characteristics for all individual plants $(n=80)$ in the data set.

\begin{tabular}{llcccc}
\hline Dependent variable & df & Mean & SD & F-value & Pr $>$ F \\
\hline Sphericity $^{z}$ & 79 & 81.54 & 0.37 & 53.71 & $<0.0001$ \\
Kernel length (mm) & 79 & 15.18 & 2.10 & 50.26 & $<0.0001$ \\
Kernel width (mm) & 79 & 11.82 & 1.25 & 19.48 & $<0.0001$ \\
Kernel depth (mm) & 79 & 10.35 & 1.38 & 24.36 & $<0.0001$ \\
Kernel weight (g) & 79 & 0.88 & 0.24 & 23.53 & $<0.0001$ \\
Shell weight (g) & 79 & 1.16 & 0.37 & 31.67 & $<0.0001$ \\
Kernel (\%) & 79 & 43.46 & 6.43 & 22.81 & $<0.0001$ \\
\hline
\end{tabular}

${ }^{2}$ Sphericity $=\Phi=[D g / \mathrm{L}] \times 100$, where $D g=(\mathrm{LWT})^{1 / 3}, \mathrm{~L}=$ length, $\mathrm{W}=$ width, and T $=$ thickness $($ depth $)$ of kernel in millimeters.

${ }^{y}$ Kernel $\%=$ kernel weight/intact nut weight $\times 100$.

'Gasaway' $R$-gene and were reported to be robust and useful for MAS (Sathuvalli and Mehlenbacher, 2010). Leaf tissue samples were stored at $-80{ }^{\circ} \mathrm{C}$ until DNA extraction. For each sample, $\approx 350 \mathrm{mg}$ of frozen tissue was ground using a mortar and pestle and genomic DNA was extracted using a modified CTAB extraction protocol (Jobes et al., 1995; Saghai-Maroof et al., 1984). DNA was quantified with a NanoDrop ND-1000 Spectrophotometer (Thermo Scientific Inc., Billerica, MA) and diluted to a concentration of $25 \mathrm{ng} / \mu \mathrm{L}$. Polymerase chain reactions (PCRs) followed the protocol developed by Honig et al. (2010). PCR products were run on an ABI $3500 x 1$ capillary electrophoresis genetic analyzer (Applied Biosystems, Foster City, CA) and sized using the GeneScan ${ }^{\mathrm{TM}}$ Liz $1200^{\circledR}$ size standard. PCR reactions produced the expected single band products with no nonspecific amplification products. Sixteen control plants were included in the SCAR primer screening for comparison with the resistant seedlings. These included EFBresistant cultivars and seedlings known to express the 'Gasaway' $R$-gene based on parentage ('Gasaway', 'Santiam', 'Zimmerman', VR 20-11, and Rutgers breeding selections H3BR3P23 and H3BR3P10), EFB-resistant plants believed to be unrelated to 'Gasaway' ('Ratoli', 'Culpla', OSU 408.040, and OSU 495.072), and several cultivars that are known to be susceptible to EFB ('Barcelona', 'DuChilly', 'Ennis', 'Casina', and 'Cutleaf'). Each 96-well plate sample run also included one well with a GeneScan installation standard (Applied Biosystems). Nearly all samples were replicated four times for each primer pair. Each genotype was scored using Genemapper 4.0 (Applied Biosystems) for the presence or absence of the specific peaks associated with each primer.

\section{Results and Discussion}

At final evaluation, 76 seedlings showed no signs of the pathogen or symptoms of the disease (rating $=0$ ) with nine expressing only minor EFB (rating 1 or 2). Most other seedlings were highly susceptible with 1780 of $1844(93 \%)$ rating 4 or 5 (Table 1$)$. The resistant and highly tolerant seedlings spanned 24 of 66 seed lots representing all three countries (Russia, Ukraine, Poland). Five of these seed lots (04030 R, RUS-2, RUS-4, RUS-11, and RUS-26) contained a higher proportion of resistant plants relative to the others. Together, they held a majority of the resistant/highly tolerant plants identified in the study ( 55 of the 85 total). The remaining $30 \mathrm{resistant/highly} \mathrm{tolerant} \mathrm{plants} \mathrm{were} \mathrm{spo-}$ radically distributed across the other seed lots.

Hazelnut is an obligate outcrossing, windpollinated species with a sporophytic selfincompatibility system (Mehlenbacher, 1997). All of the seedlings evaluated were derived from open-pollinated nuts, and we expect that the pollen parents were very diverse. A large number of the seed lots was harvested from germplasm collections holding many different, potentially intercrossing cultivars and seedling accessions. Furthermore, C. avellana is a common understory shrub and a component of many landscape plantings and gardens across the regions where the nuts were collected. Thus, for many seed lots, pollen could have come from wild plants as well as a variety of locally grown trees, some of which themselves would have been propagated by seed. For the majority of seed lots holding only one or two resistant plants such as $06080 \mathrm{P}$ from Warsaw, Poland, based on the unknown female parent and diverse pollen sources, it is not possible to discern the origin of genes for resistance or speculate with any certainty on the genetic control of the resistance present. As a consequence, the results simply identify a number of new, potentially very valuable hazelnut genotypes remaining free of EFB in New Jersey that merit further study. However, the significant clustering of resistant plants in five of the seed lots mentioned previously, including the bimodal pattern of resistance observed within several of them (i.e., the presence of only clearly resistant or highly susceptible trees with few intermediate responses shown), provides an indication that dominant, simply inherited resistance genes may be present in some of their progeny. As an example, seed lot $04030 \mathrm{R}$ ['Moskovski Rubin' $\times$ open-pollination (OP)], 18 of 54 $(33 \%)$ trees rated 0 , one rated 4 , and the remaining 35 rated 5 . This pattern was very similar to that observed for RUS-2 ('Kudishovski' $\times$ OP), where 23 of $61(38 \%)$ trees rated 0 , two rated 4 , and 36 rated 5 . These seed lots were both collected from the hazelnut germplasm collection located at the Russian Academy of Agricultural Science Institute of Floriculture and Subtropical Cultures, Sochi, Russia, although in different years. Their results, especially when compared with the numerous 
Table 3. Nut and kernel characteristics of select eastern filbert blight (EFB)-resistant ${ }^{\mathrm{z}}$ hazelnut (Corylus avellana) selections from Russia and Ukraine.

\begin{tabular}{|c|c|c|c|c|c|c|c|c|c|c|c|c|c|c|}
\hline \multirow[b]{2}{*}{ Plant ID } & \multirow[b]{2}{*}{ Seed lot } & \multirow[b]{2}{*}{ Kernel wt $(\mathrm{g})^{\mathrm{y}}$} & \multirow[b]{2}{*}{ Kernel $\%{ }^{\mathrm{x}}$} & \multicolumn{4}{|c|}{ Avg kernel dimensions } & \multirow[b]{2}{*}{ Fiber $^{v}$} & \multirow[b]{2}{*}{ Pellicle $^{\mathrm{u}}$} & \multicolumn{5}{|c|}{ Percent of nuts in each category ${ }^{t}$} \\
\hline & & & & Length & Width & Depth & Sphericity $^{\mathrm{w}}$ & & & Good & Blank & Moldy & SH & $\mathrm{PF}$ \\
\hline CRRR06P02 & 04024R & 0.72 & 47.72 & 13.91 & 11.38 & 10.01 & 83.9 & 1 & 4 & 42.5 & 50.0 & 2.5 & 5.0 & 0.0 \\
\hline CRRR05P32 & 04026R & 1.01 & 46.72 & 13.73 & 12.84 & 11.84 & 93.1 & 2 & 1 & 82.0 & 8.0 & 2.0 & 0.0 & 8.0 \\
\hline CRRR04P116 & 04028R & 0.81 & 33.46 & 13.79 & 11.66 & 10.54 & 86.9 & 3 & 4 & 76.0 & 16.0 & 0.0 & 6.0 & 2.0 \\
\hline CRRR04P28 & 04030R & 1.35 & 50.97 & 18.16 & 13.04 & 11.12 & 76.0 & 2 & 3 & 70.0 & 8.0 & 8.0 & 8.0 & 6.0 \\
\hline CRRR04P48 & 04030R & 1.09 & 43.79 & 15.92 & 12.75 & 11.22 & 82.6 & 3 & 2 & 86.0 & 2.0 & 2.0 & 10.0 & 0.0 \\
\hline CRRR04P64 & 04030R & 0.96 & 42.94 & 14.02 & 12.73 & 11.23 & 89.9 & 1 & 6 & 84.4 & 6.3 & 3.1 & 6.3 & 0.0 \\
\hline CRRR03P11 & 04034R & 1.05 & 42.49 & 14.86 & 13.51 & 11.18 & 88.1 & 3 & 6 & 58.0 & 16.0 & 2.0 & 16.0 & 6.0 \\
\hline CRRR02P96 & 04038R & 1.00 & 44.15 & 17.41 & 10.99 & 9.35 & 69.6 & 3 & 1 & 86.0 & 2.0 & 0.0 & 8.0 & 4.0 \\
\hline CRRR02P41 & 04040R & 0.96 & 35.58 & 15.26 & 13.17 & 11.06 & 85.5 & 3 & 6 & 54.0 & 28.0 & 0.0 & 16.0 & 2.0 \\
\hline CRRR01P116 & 04041R & 0.60 & 32.72 & 13.77 & 10.22 & 8.35 & 76.7 & 1 & 6 & 78.1 & 3.1 & 0.0 & 9.4 & 9.4 \\
\hline H3R10P94s & RUS-1 & 0.71 & 41.67 & 12.83 & 12.01 & 9.59 & 88.8 & 2 & 7 & 82.0 & 6.0 & 4.0 & 4.0 & 4.0 \\
\hline CRXR13P78 & RUS-2 & 1.17 & 47.52 & 18.22 & 12.28 & 11.22 & 74.6 & 4 & 6 & 84.0 & 0.0 & 6.0 & 10.0 & 0.0 \\
\hline CRXR13P83 & RUS-2 & 0.95 & 51.83 & 13.72 & 12.20 & 11.24 & 90.0 & 1 & 6 & 58.0 & 30.0 & 0.0 & 10.0 & 2.0 \\
\hline CRXR13P91 & RUS-2 & 1.26 & 52.26 & 17.90 & 12.68 & 11.28 & 76.5 & 4 & 7 & 64.0 & 8.0 & 12.0 & 10.0 & 6.0 \\
\hline CRXR14P34 & RU2-4 & 0.79 & 41.36 & 12.40 & 12.01 & 11.40 & 96.3 & 2 & 2 & 78.0 & 14.0 & 4.0 & 4.0 & 0.0 \\
\hline CRXR14P117 & RUS-7 & 0.95 & 36.33 & 15.85 & 12.73 & 11.37 & 83.3 & 1 & 2 & 62.0 & 4.0 & 16.0 & 14.0 & 4.0 \\
\hline H3R13P40 & RUS-9 & 1.31 & 47.87 & 14.94 & 14.30 & 13.78 & 96.0 & 1 & 2 & 72.0 & 8.0 & 4.0 & 12.0 & 4.0 \\
\hline CRXR15P59 & RUS-11 & 0.86 & 38.71 & 13.44 & 12.62 & 11.90 & 94.1 & 2 & 6 & 62.0 & 20.0 & 4.0 & 12.0 & 2.0 \\
\hline H3R07P25 & RUS-12 & 0.70 & 40.75 & 12.58 & 11.29 & 9.66 & 88.3 & 1 & 3 & 90.0 & 6.0 & 2.0 & 2.0 & 0.0 \\
\hline H3R04P23 & RUS-13 & 0.91 & 43.38 & 12.93 & 11.98 & 11.39 & 93.5 & 1 & 6 & 86.0 & 8.0 & 0.0 & 0.0 & 6.0 \\
\hline CRXR17P48 & RUS-15 & 0.94 & 46.28 & 15.73 & 12.65 & 10.95 & 82.4 & 4 & 4 & 40.0 & 30.0 & 24.0 & 6.0 & 0.0 \\
\hline H3R14P26 & RUS-22 & 1.11 & 39.74 & 13.20 & 12.02 & 11.38 & 92.3 & 1 & 4 & 48.0 & 0.0 & 0.0 & 24.0 & 28.0 \\
\hline H3R12P62 & RUS-23 & 0.78 & 41.08 & 15.11 & 10.62 & 9.73 & 76.8 & 4 & 4 & 90.0 & 2.0 & 4.0 & 4.0 & 0.0 \\
\hline CRXR19P21 & RUS-25 & 0.51 & 34.07 & 12.37 & 11.03 & 8.83 & 86.0 & 3 & 3 & 56.0 & 18.0 & 8.0 & 16.0 & 2.0 \\
\hline H3R07P07 & RUS-26 & 0.88 & 42.71 & 12.97 & 12.25 & 11.45 & 94.1 & 4 & 5 & 94.0 & 2.0 & 0.0 & 4.0 & 0.0 \\
\hline H3R07P09 & RUS-26 & 0.72 & 40.71 & 12.43 & 11.51 & 10.74 & 92.9 & 3 & 5 & 86.0 & 2.0 & 0.0 & 12.0 & 0.0 \\
\hline H3R10P88 & RUS-28 & 0.93 & 50.33 & 13.49 & 12.60 & 12.01 & 94.1 & 1 & 1 & 72.0 & 6.0 & 6.0 & 14.0 & 2.0 \\
\hline Barcelona $^{r}$ & NA & 1.48 & 42.26 & 16.73 & 15.34 & 14.41 & 92.5 & 3 & 3 & 63.6 & 6.0 & 2.6 & 1.6 & 21.8 \\
\hline Delta & NA & 1.17 & 49.83 & 13.98 & 13.38 & 12.62 & 95.3 & 2 & 5 & 60.0 & 30.0 & 8.0 & 2.0 & 0.0 \\
\hline \multirow[t]{2}{*}{ Gasaway } & NA & 0.44 & 43.12 & 13.81 & 10.39 & 8.56 & 77.5 & 3 & 7 & 72.0 & 10.0 & 0.0 & 6.0 & 12.0 \\
\hline & LSD $(0.05)$ & 0.12 & 3.17 & 0.76 & 0.65 & 0.66 & 3.1 & & & & & & & \\
\hline
\end{tabular}

${ }^{\mathrm{z} C R R R 06 P 02}$ and Gasaway were rated 1 (one small canker), whereas all other selections were rated 0 (no signs or symptoms of EFB).

${ }^{\mathrm{y}}$ All kernel characteristics (weight, \%, average kernel dimensions, sphericity, fiber, and pellicle) are based on 10 samples representing typical kernels from each plant.

${ }^{\mathrm{x}}$ Kernel percent $=$ kernel weight/total nut weight $\times 100$.

${ }^{\text {w }}$ Sphericity $=\Phi=[D g / \mathrm{L}] \times 100$, where $D g=(\mathrm{LWT})^{1 / 3}, \mathrm{~L}=$ length, W $=$ width, and $\mathrm{T}=$ thickness $($ depth $)$ of kernel in millimeters: $=\Phi=[D g / \mathrm{L}] \times 100$, where $\mathrm{L}=$ length, $\mathrm{W}=$ width, and $\mathrm{T}=$ thickness in $\mathrm{mm}$.

vFiber is rated on a scale of 1 (no fiber) to 4 (very fibrous).

uPellicle is rated on a scale of 1 (all pellicle is removed) to 7 (little to no pellicle is removed) after dry roasting at $130{ }^{\circ} \mathrm{C}$ for 13.5 min

tPercent of nuts in each category [good, blank, moldy, shriveled (SH), and poorly filled (PF)] is based on 50 total nuts for each plant, except for CRR06P02 (40 nuts) and CRRR04P64 and CRRR01P116 (32 nuts each). CRRR03P11 also had one twinned kernel, which was not retained as a category in the table because there were no other twinned kernels found.

"Accessions with an "H3R" designation were identified as being EFB-resistant in Molnar et al. (2007).

r'Barcelona' percent of nuts in each category (good, blank, etc.) is adapted from Mehlenbacher et al. (2011). In that report, 'Barcelona' also has 4\% twin kernels and $1.5 \%$ brown stain (total is over $100 \%$ ).

$\mathrm{NA}=$ not applicable; $\mathrm{LSD}=$ least significant difference.

other seed lots collected from cultivars at the same institute that held few or no resistant trees, suggest that a dominant, simply inherited resistance gene (or genes) is present in both 'Moskovski Rubin' and 'Kudishovski'. Both cultivars are believed to have originated from a breeding program located near Moscow, Russia (Kudasheva, 1965; Yablokov, 1962), where germplasm is still held by the Russian Research Institute of Forestry and Mechanization. They also share a major similarity in that both have purple leaves (their seedlings also segregated for purple leaves in our trials). Interestingly, Sathuvalli et al. (2010) identified five clonal accessions from the Russian Research Institute of Forestry and Mechanization that were also EFB-resistant: Moscow \#1, $\# 2$, \#26, \#27, and \#37. Several of this group, including Moscow \#2, have purple leaves. Moscow \#2 was also found to remain free of EFB after field exposure in New Jersey (Capik and Molnar, 2012). These commonalities, further supported by the general rarity of EFB resistance in $C$. avellana, make it probable that our resistant seedlings from RUS-2 and $04030 \mathrm{R}$ share a common ancestor or lineage with these Moscow resistant selections and likely the same gene(s) for EFB resistance.

Seed lots RUS-4 from Sochi, RUS-26 from Simferopol, Ukraine, and RUS-11 from Holmskij, Russia, also produced a relatively large proportion of resistant and highly tolerant trees, amounting to $32 \%, 31 \%$, and $17 \%$ of each of their total, respectively. Their results also suggest that a dominant gene (or genes) for resistance is present in the progeny. Unfortunately, these seed lots represent nuts purchased at local markets and little is known of their origin with some seed lots possibly consisting of mixtures of nuts from different parents. As a result of the lack of information on the seed lots and few comparative progeny, it is hard to speculate on the origin of resistance. Regardless, the likely presence of simply inherited resistance genes is very promising. We suspect these nuts were harvested from local hazelnut sources based on the rural setting of the small, roadside markets in which the seed lots were purchased. If this assumption is correct, these plants probably represent germplasm not closely related to seedlings of $04030 \mathrm{R}$ and RUS-2, which originate from near Moscow, and they may express novel genes for EFB resistance. Further testing, including the placement of $R$-genes on the hazelnut genetic linkage map (Mehlenbacher et al., 2006), will be necessary to draw stronger conclusions on the nature and relationships of genes for EFB resistance between these or any of the other resistant plants identified in this study.

Sufficient numbers of nuts were available for evaluation of nut and kernel attributes from 64 of the total 81 plants that were rated 0 or 1 for EFB response (Table 1) and all 13 EFB-resistant plants identified in Molnar et al. (2007). No nuts were collected from the Polish plants (a total of nine resistant/ tolerant trees) because they were not yet bearing appreciable numbers of nuts or were subjected to heavy rodent predation in 2012 . The ANOVA revealed significant differences 
in kernel attributes among plants (Tables 2 and 3). Table 3 provides kernel data for selected EFB-resistant plants and includes representation from 22 different seed lots [six of the plants from Molnar et al. (2007) originated from seed lots not holding resistant plants in this study] in addition to the EFB-resistant cultivars Gasaway and Delta and susceptible 'Barcelona' for comparison. Based on the nut evaluations, we identified several trees that produce nuts of improved quality, including round kernels that blanch well and have a low percentage of defects (Fig. 1). For example, selection H3R10P88 (RUS-28, Yalta, Crimea, Ukraine) produces nuts with a kernel to shell ratio of $50.3 \%$ and round (average sphericity of 94.1 ), $\approx 12-\mathrm{mm}$ diameter kernels that blanch almost completely (pellicle removal rating of 1). Selection CRRR05P32 (04026 R, Sochi, Russia) had an average kernel to shell ratio of $46.7 \%$ with round (average sphericity of 93.1), $\approx 12$-mm diameter kernels that also blanched almost completely (pellicle removal rating of 1). Furthermore, selection H3R13P40 (RUS-9, Holmskij, Russia) produced nuts with an average kernel to shell ratio of $47.9 \%$ with round (average sphericity of 96.0), $\approx 14-\mathrm{mm}$ diameter kernels that blanch well (pellicle removal rating of 2 ). It should be noted that these evaluations represent only one year of data and should be considered a preliminary assessment. However, a number of these traits has been previously shown to be under relatively strong genetic control such as kernel weight, kernel dimensions, kernel to shell ratio, and presence of mold (Mehlenbacher et al., 1993; Thompson, 1977; Yao and Mehlenbacher, 2000) and would be expected to remain relatively consistent across years. Our results show a number of the new accessions represent significant improvements over 'Gasaway' in terms of kernel characteristics and presence of defects, supported by the fact that the plants were all grown in the same location where environmental variation across the site was negligible. If resistance is found to be transmitted in a dominant manner, as is suggested by the disease response observed in

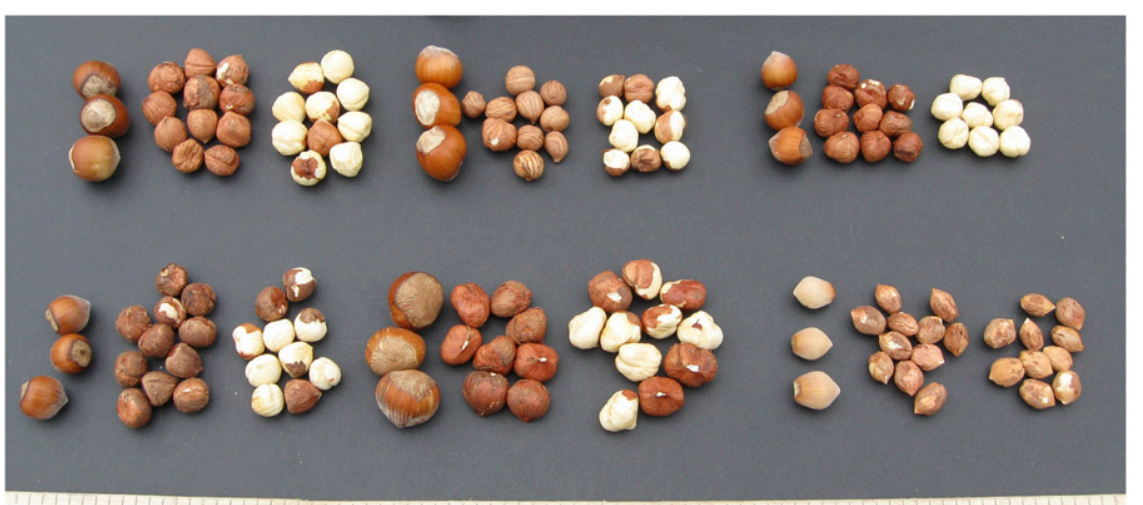

Fig. 1. Whole nuts, raw kernels, and blanched kernels of select eastern filbert blight (EFB)-resistant hazelnut accessions. Top row left to right: H3R13P40, H3R14P26, and H3R10P88. Bottom row left to right: 'Santiam' (Mehlenbacher et al., 2007), 'Barcelona' (susceptible), and 'Gasaway'. some of the seed lots, some of these new accessions may prove to be of considerable value to breeding EFB-resistant hazelnuts with improved nut and kernel characteristics.

The results of the 'Gasaway' SCAR primer assessment were largely inconclusive. The SCAR marker primers proved capable of amplifying clear, distinct alleles for each marker; however, the presence/absence of alleles showed a poor correlation with known resistance or susceptible phenotypes. As expected, the six control plants known to express markers linked to the Gasaway $R$-gene amplified alleles from all three SCAR marker primers; however, two of the four known EFB-resistant control plants unrelated to 'Gasaway', OSU 408.040 (from Minnesota) and OSU 495.072 (from southern Russia), amplified alleles from BE33 and BE03, respectively. Additionally, of the five known EFB-susceptible control plants included in the current study ('Barcelona', 'DuChilly', 'Ennis', 'Casina', and 'Cutleaf'), 'Casina' amplified alleles from two of the SCAR marker primers, whereas 'Cutleaf' amplified alleles from all three SCAR marker primers. It is interesting to note that none of the 83 resistant seedlings amplified alleles from all three primers; however, a number of the seedlings amplified alleles by one or occasionally two of the primers (data not shown). From these results, it was difficult to draw strong conclusions on the presence of the 'Gasaway' $R$-gene in the seedlings. The goal of the SCAR marker screening was to ascertain information on the likely presence of the 'Gasaway' $R$-gene in the new germplasm. 'Gasaway' has been widely used in breeding EFB-resistant hazelnuts and unrelated sources of EFB resistance are desired to augment prior improvement efforts and for the pyramiding of resistance genes to develop plants expressing more durable forms of resistance.

At the initiation of this study, the use of closely linked 'Gasaway' SCAR markers was considered a reasonable and valid approach to evaluate the seedlings for the potential presence of their target allele, especially based on the proven effectiveness of the
'Gasaway' RAPD markers for use in MAS within progeny segregating for presence of the allele at OSU. Our results showed the limitation of these markers when assessing a diverse and largely unknown pool of genotypes. Given our inconclusive results, recent findings may provide some insight into what may be occurring. Work by Peterschmidt et al. (2012) and Sathuvalli et al. (2012) showed that resistance derived from OSU 408.040, OSU 495.072, and 'Culpla' mapped to the same linkage group (LG6) and in close proximity to the 'Gasaway' $R$-gene locus, indicating a possible $R$-gene cluster associated with their resistant phenotypes. Under such a scenario, it is plausible to see amplification by one or more of the SCAR markers in other European hazelnuts showing resistance to EFB if the 'Gasaway' $R$-gene represents a component of a cluster of conserved genes that provide a level of resistance or tolerance to infection by $A$. anomala. However, it was surprising to see amplification by all three markers in 'Cutleaf' and two of the three in 'Casina', which are known to be highly susceptible to EFB. Thus, the results remain inconclusive and point to a significant need to develop additional molecular tools (through map-based cloning, sequencing, and validating candidate $R$-genes, etc.) to assist in the identification and characterization of resistance alleles. Currently, very little is known about the mechanism of resistance associated with the 'Gasaway' $R$-gene or other resistance genes in hazelnut. These understandings are vital when working with perennial crops such as hazelnut that have long generation times.

Regardless of the SCAR marker results, the field data show that many of the new selections still remain free of EFB after many years in the field, whereas plants carrying the 'Gasaway' $R$-gene have shown an increased degree of susceptibility in New Jersey (Capik and Molnar, 2012; Molnar et al., 2010b). This includes several progeny segregating for a high level of resistance without individuals showing the tolerant phenotypes (EFB rating of 1,2 , and 3 ) observed in progenies segregating for the 'Gasaway' gene in New Jersey (Molnar, unpublished data). As such, their phenotypes, in conjunction with the diverse origins of the plant material, suggest that novel sources of EFB resistance exist in some of the seedlings. Additional research such as discovery of new genes/quantitative trait loci through developing mapping populations, test crosses, etc., will be needed to prove this hypothesis. Work along these lines is currently being conducted.

\section{Conclusions}

This study yielded a relatively large number of new seedlings of $C$. avellana shown to express resistance or a high level of tolerance to EFB. Some of these plants have remained disease-free or have expressed only very limited infections after nearly a decade of exposure to A. anomala in New Jersey under high disease pressure. Although confounded 
by the fact that all of the seedlings are derived from OP nuts, the clustering of resistant seedlings in several seed lots suggests that some accessions may hold simply inherited, dominant genes for EFB resistance. More work is needed to better understand the EFB resistance expressed across the numerous seedlings identified in this study, including the relationships of the resistance alleles and how they are inherited. However, based on the diversity of origins represented in the collection and the outcrossing nature of hazelnuts along with the high level of disease resistance observed, we hope that further research will reveal a number of novel genes for EFB resistance.

Although the results of the 'Gasaway' SCAR primer assessment were largely inconclusive, they shed light on the challenges associated with breeding for disease resistance in a perennial, clonally propagated crop with a long generation time and support the great need for the development of additional molecular-based tools for use in such a system. Future work will include the characterization of the EFB-tolerant and -resistant trees using simple sequence repeat (SSR) markers (Bassil et al., 2013; Boccacci et al., 2005; Gürcan et al., 2010). They will be analyzed alongside cultivars and accessions representing known geographic origins such as those discussed in Gökirmak et al. (2009). This work will help us better determine origins and relationships within our collection and between other known EFB-resistant cultivars and selections, including OSU 495.072 from southern Russia and the aforementioned Moscow \#1, \#2, \#26, \#27, and \#37 (Sathuvalli et al., 2010) as well as OSU 759.010 from the Republic of Georgia (Sathuvalli et al., 2011b).

The top EFB-resistant performers of this new collection will be assessed for use in the Rutgers genetic improvement program, including the study of inheritance of resistance of their progeny and the placing of resistance genes, where applicable, on the hazelnut genetic linkage map (Mehlenbacher et al., 2006). The most promising seedlings will also be propagated and made available to OSU and the U.S. Department of Agriculture, Agricultural Research Service, National Clonal Germplasm Repository in Corvallis, OR.

\section{Literature Cited}

Barss, H.P. 1930. Eastern filbert blight. California Dept. Agr. Bul. 19:489-490.

Bassil, N.V., P. Boccacci, R. Botta, J. Postman, and S.A. Mehlenbacher. 2013. Nuclear and chloroplast microsatellite markers to assess genetic diversity and evolution in hazelnut species, hybrids and cultivars. Genet. Resources Crop Evol. 60:543-568.

Boccacci, P., A. Akkak, N.V. Bassil, S.A. Mehlenbacher, and R. Botta. 2005. Characterization and evaluation of microsatellite loci in European hazelnut (Corylus avellana L.) and their transferability to other Corylus species. Mol. Ecol. Notes 5:934-937.

Capik, J.M. and T.J. Molnar. 2012. Assessment of host (Corylus sp.) resistance to eastern filbert blight in New Jersey. J. Amer. Soc. Hort. Sci. 137:157-172.
Chen, H., S.A. Mehlenbacher, and D.C. Smith. 2005. AFLP markers linked to eastern filbert blight resistance from OSU 408.040 hazelnut. J. Amer. Soc. Hort. Sci. 130:412-417.

Chen, H., S.A. Mehlenbacher, and D.C. Smith. 2007. Hazelnut accessions provide new sources of resistance to eastern filbert blight. HortScience 42:466-469.

Coyne, C.J., S.A. Mehlenbacher, K.B. Johnson, J.N. Pinkerton, and D.C. Smith. 2000. Comparison of two methods to evaluate quantitative resistance to eastern filbert blight in European hazelnut. J. Amer. Soc. Hort. Sci. 125:603-608.

Coyne, C.J., S.A. Mehlenbacher, and D.C. Smith 1998. Sources of resistance to eastern filbert blight. J. Amer. Soc. Hort. Sci. 124:253-257.

Davison, A.D. and R.M. Davidson. 1973. Apioporthe and Monchaetia canker reported in western Washington. Plant Dis. Rptr. 57:522-523.

Erdogan, V. and S.A. Mehlenbacher. 2000. Phylogenetic relationships of Corylus species (Betulaceae) based on nuclear ribosomal DNA ITS region and chloroplast matK gene sequences. Syst. Bot. 25:727-737.

Food and Agriculture Organization of the United Nations. 2012. Agricultural production, crops primary. FAO, Geneva. 5 Sept. 2012. <http:// faostat.fao.org/site/567/default.aspx\#ancor>.

Fuller, A.S. 1908. The nut culturist. Orange Judd, New York, NY.

Gleason, H.A. and A. Cronquist. 1998. Manual of vascular plants of northeastern United States and adjacent Canada. The New York Botanical Gardens, Bronx, NY.

Gökirmak, T., S.A. Mehlenbacher, and N.V. Bassil 2009. Characterization of European hazelnut (Corylus avellana $\mathrm{L}$.) cultivars using SSR markers. Genet. Resources Crop Evol. 56:147-172.

Gottwald, T.R. and H.R. Cameron. 1980. Disease increase and the dynamics of spread of canker caused by Anisogramma anomala in European filbert in the Pacific Northwest. Phytopathology 70:1087-1092.

Gürcan, K., S.A. Mehlenbacher, R. Botta, and P. Boccacci. 2010. Development, characterization, segregation, and mapping of microsatellite markers for European hazelnut (Corylus avellana L.) from enriched genomic libraries and usefulness in genetic diversity studies. Tree Genet. Genomes 6:513-531.

Honig, J.A., S.A. Bonos, and W.A. Meyer. 2010. Isolation and Characterization of 88 Polymorphic Microsatellite Markers in Kentucky Bluegrass (Poa pratensis L.). HortScience 45:1759-1763.

Jobes, D.V., D.L. Hurley, and L.B. Thien. 1995. Plant DNA isolation: a method to efficiently remove polyphenolics, polysaccharides, and RNA. Taxon 44:379-386.

Johnson, K.B., S.A. Mehlenbacher, J.K. Stone, and J.W. Pscheidt. 1996. Eastern filbert blight of European hazelnut: It's becoming a manageable disease. Plant Dis. 80:1308-1316.

Johnson, K.B. and J.N. Pinkerton. 2002. Eastern filbert blight, p. 44-46. In: Teviotdale, B.L., T.J. Michailides, and J.W. Pscheidt (eds.). Compendium of nut crop diseases in temperate zones. APS Press, Amer. Phytopathol. Soc., St. Paul, MN.

Johnson, K.B., J.N. Pinkerton, S.M. Gaudreault, and J.K. Stone. 1994. Infection of European hazelnut by Anisogramma anomala: Site of infection and effect on host developmental stage. Phytopathology 4:1465-1470.

Julian, J., C. Seavert, and J.L. Olsen. 2009. An economic evaluation of the impact of eastern filbert blight resistant cultivars in Oregon, U.S.A. Acta Hort. 845:725-732.
Julian, J.W., C.F. Seavert, and J.L. Olsen. 2008. Orchard economics: The costs and returns of establishing and producing hazelnuts in the Willamette Valley. OR. State Univ. Ext. Serv. Bul. EM 8748-E.

Kudasheva, R.F. 1965. Propagation and breeding of wild and cultivated hazel nuts [in Russian]. Lesnaya Promishlennost, Moscow, Russia.

Lunde, C.F., S.A. Mehlenbacher, and D.C. Smith. 2000. Survey of hazelnut cultivars for response to eastern filbert blight inoculation. HortScience 35:729-731.

Mehlenbacher, S.A. 1991. Hazelnuts (Corylus), p. 789-836. In: Moore, J.N. and J.R. Ballington (eds.). Genetic resources of temperate fruit and nut crops. Int. Soc. Hort. Sci., Wageningen, The Netherlands.

Mehlenbacher, S.A. 1994. Genetic improvement of the hazelnut. Acta Hort. 351:23-38.

Mehlenbacher, S.A. 1997. Revised dominance hierarchy for S-alleles in Corylus avellana L. Theor. Appl. Genet. 94:360-366.

Mehlenbacher, S.A., A.N. Azarenko, D.C. Smith, and R.L. McCluskey. 2007. 'Santiam' hazelnut. HortScience 42:715-717.

Mehlenbacher, S.A., R.N. Brown, J.W. Davis, H. Chen, N.V. Bassil, D.C. Smith, and T.L. Kubisiak. 2004. RAPD markers linked to eastern filbert blight resistance in Corylus avellana. Theor. Appl. Genet. 108:651-656.

Mehlenbacher, S.A., R.N. Brown, E.R. Nouhra, T. Gökirmak, N.V. Bassil, and T.L. Kubisiak. 2006. A genetic linkage map for hazelnut (Corylus avellana L.) based on RAPD and SSR markers. Genome 49:122-133.

Mehlenbacher, S.A. and D.C. Smith. 1988. Heritability of ease of hazelnut pellicle removal. HortScience 23:1053-1054.

Mehlenbacher, S.A., D.C. Smith, and L.K. Brenner. 1993. Variance components and heritability of nut and kernel defects in hazelnut. Plant Breed. 110:144-152.

Mehlenbacher, S.A., D.C. Smith, and R. McCluskey. 2011. 'Jefferson' hazelnut. HortScience 46:662664.

Mehlenbacher, S.A., D.C. Smith, and R.L. McCluskey. 2009. 'Yamhill' hazelnut. HortScience 44:845847.

Mehlenbacher, S.A., M.M. Thompson, and H.R. Cameron. 1991. Occurrence and inheritance of immunity to eastern filbert blight in 'Gasaway' hazelnut. HortScience 26:410-411.

Mohsenin, N.N. 1970. Physical properties of plant and animal materials. Gordon and Breach Science Publishers, New York, NY.

Molnar, T.J., J.C. Goffreda, and C.R. Funk. 2005a. Developing hazelnuts for the eastern United States. Acta Hort. 68:609-617.

Molnar, T.J., S.N. Baxer, and J.C. Goffreda. 2005b. Accelerated screening of hazelnut seedlings for resistance to eastern filbert blight. HortScience 40:1667-1669.

Molnar, T.J., J.C. Goffreda, and C.R. Funk. 2010a. Survey of Corylus resistance to Anisogramma anomala from different geographic locations. HortScience 45:832-836.

Molnar, T.J., J. Capik, S. Zhao, and N. Zhang. 2010b. First report of eastern filbert blight on Corylus avellana 'Gasaway' and 'VR20-11' caused by Anisogramma anomala (Peck) E. Müller in New Jersey. Plant Dis. 94:1265.

Molnar, T.J., S.A. Mehlenbacher, D.E. Zaurov, and J.C. Goffreda. 2007. Survey of hazelnut germplasm from Russia and Crimea for response to eastern filbert blight. HortScience 42:5156.

Peterschmidt, B.C., S.A. Mehlenbacher, and V. Sathuvalli. 2012. Novel sources of eastern 
filbert blight resistance in 'Culpla' and OSU 495.072 hazelnuts. HortScience 47:S362 (Abstr.) 15 Jan. 2013. <http://www.ashs.org/downloads/ supplement/2012ASHS-AnnualConference.pdf $>$.

Pinkerton, J.N., K.B. Johnson, K.M. Theiling, and J.A. Griesbach. 1992. Distribution and characteristics of the eastern filbert blight epidemic in western Oregon. Plant Dis. 76:1179-1182.

Saghai-Maroof, M.A., K.M. Soliman, R.A. Jorgensen, and R.W. Allard. 1984. Ribosomal DNA spacerlength polymorphisms in Barley: Mendelian inheritance, chromosomal location and population dynamics. Proc. Natl. Acad. Sci. USA 81:8014-8018.

SAS Institute, Inc. 2012. SAS/STAT 9.22 Users Guide. 24 Jan. 2012. <http://support.sas.com/ documentation/cdl/en/statug/63347/HTML/ default/viewer.htm\#statug_glm_sect018.htm>.

Sathuvalli, V. and S.A. Mehlenbacher. 2010. Fine mapping of eastern filbert blight resistance in hazelnut with SCAR and SSCP markers developed from BAC end sequences. Acta Hort. 859:395-400.
Sathuvalli, V., S.A. Mehlenbacher, and D.C. Smith. 2009. New sources of eastern filbert blight and linked markers. Acta Hort. 845:123-126.

Sathuvalli, V., S.A. Mehlenbacher, and D.C. Smith. 2010. Response of hazelnut accessions to greenhouse inoculation with Anisogramma anomala. HortScience 45:1116-1119.

Sathuvalli, V.R., H.L. Chen, S.A. Mehlenbacher, and D.C. Smith. 2011a. DNA markers linked to eastern filbert blight resistance in 'Ratoli' hazelnut. Tree Genet. Genomes 7:337-345.

Sathuvalli, V., S.A. Mehlenbacher, and D.C. Smith. 2011b. DNA markers linked to eastern filbert blight resistance from a hazelnut selection from the Republic of Georgia. J. Amer. Soc. Hort. Sci. 136:350-357.

Sathuvalli, V.R., H.L. Chen, S.A. Mehlenbacher, and D.C. Smith. 2012. Identification and mapping of DNA markers linked to eastern filbert blight resistance from OSU 408.040 hazelnut. HortScience 47:570-573.

Sathuvalli, V.R. and S.A. Mehlenbacher. 2012. Characterization of American hazelnut (Corylus americana) accessions and Corylus americana $\times$ Corylus avellana hybrids using microsatellite markers. Genet. Resources Crop Evol. 59:10551075.

Thompson, M.M. 1977. Inheritance of nut traits in filbert. Euphytica 26:465-474.

Thompson, M.M., H.B. Lagerstedt, and S.A. Mehlenbacher. 1996. Hazelnuts, p. 125-184. In: Janick, J. and J.N. Moore (eds.). Fruit breeding. Vol. 3. Nuts. Wiley, New York, NY.

Thompson, M.M., P. Romisondo, E. Germain, R. Vidal-Barraquer, and J. Tasias-Valls. 1978. An evaluation system for filberts (Corylus avellana L.). HortScience 13:514-517.

Weschcke, C. 1954. Growing nuts in the north. Webb, St. Paul, MN.

Yablokov, A.S. 1962. Selection of woody species [in Russian]. Selkhozgiz, Moscow, Russia.

Yao, Q. and S.A. Mehlenbacher. 2000. Heritability, variance components, and correlation of morphological and phenological traits in hazelnut. Plant Breed. 119:369-381. 